\title{
Audit committees, female directors and the types of female and male financial experts: Further evidence
}

\begin{abstract}
:
Evidence on the association between female directors on audit committees and audit quality is weak. Further, researchers' failure to identify the types of female and male financial experts may have a) resulted in the mixed evidence on the relationship between female financial experts on audit committees and financial reporting monitoring, and b) led them to question male financial experts on audit committees. Thus, we examine whether female directors and the types of female and male financial experts on audit committees are associated with audit quality. Using FTSE 350 firms from 2009 to 2017 and ordinary least-squares regression, this study finds that female directors and female accounting experts on audit committees are positively associated with audit quality. Our results may explain the conflicting evidence on the association between female financial experts and financial reporting oversight and also suggest that firms' audit quality may increase with female accounting experts on audit committees.
\end{abstract}

Keywords: female directors; female and male financial experts; audit committees; audit quality 


\section{Introduction}

This research examines the impact of a female audit committee member on audit quality. Further, we investigate whether the financial expertise (both accounting and non-accounting) of female audit committee members improves audit quality. Empirical research provides evidence that the existence of female directors on the audit committee enhances earnings quality (Srinidhi, Gul, \& Tsui, 2011; Thiruvadi \& Huang, 2011). The role of an audit committee is to oversee the financial reports (Aldamen, Hollindale, \& Ziegelmayer, 2018) and thereby mitigate agency costs (Dhaliwal, Naiker, \& Navissi, 2010), suggesting the importance of audit committees. Further, Bédard and Gendron (2010) contend that audit quality is one of the mechanisms to determine audit committee effectiveness. Female directors on audit committees are expected to oversee management effectively and thereby improve audit quality because female directors are more likely to show lower tolerance towards opportunistic behaviour (Srinidhi et al., 2011; Zalata, Tauringana, \& Tingbani, 2018).

Following corporate collapses such as ENRON, policy-makers have attempted to overhaul corporate governance regulation by incorporating gender diversity in order to address the groupthink stemming from male-only boards (Wahid, 2019). Regulators in different countries have implemented mandatory female quotas. For example, Norway, Spain and France have a $40 \%$ female quota policy where non-compliance leads to sanctions such as fines, adverse impact on the award of state contracts, and the non-payment of directors' fees (Terjesen, Aguilera, \& Lorenz, 2015; Terjesen \& Sealy, 2016). On the other hand, countries like Finland, Sweden and the United Kingdom (UK) follow a voluntary approach (comply or explain principle) where firms are required to adopt and disclose their gender-diversity policies and in the case of non-compliance, provide an explanation [Financial Reporting Council (FRC), 2018; Securities Market Association, 2015; Swedish Corporate Governance Board, 2016]. However, even in the case of a voluntary approach, countries heighten the pressure on 
companies to increase female directors. For example, in the UK, government-supported reports frequently publish the progress of female directors and set voluntary targets, such as expecting FTSE 350 firms to enhance their female directors' representation to 33\% by 2020 (Department for Business, Innovation \& Skills, 2015). Our study therefore empirically investigates the beneficial effects of female directors on audit committees.

Prior research has examined the association between female directors on audit committees and audit quality but failed to adequately account for the practitioners' assessment of audit quality. Aobdia (2019) argues that the researchers' use of indirect proxies to capture unobservable audit processes is a weak approach when attempting to capture audit quality. Therefore, determining audit quality from the practitioners' (regulatory bodies and audit firms) perspective is a more effective way to ascertain audit quality given that practitioners are likely to possess more information about the appropriateness of audit (Aobdia, 2019; Bell, Causholli, \& Knechel, 2015) $)^{1}$.

The extant auditing literature provides inconclusive evidence between the association of female director presence on the audit committee and audit fees (Aldamen et al., 2018; Ittonen, Miettinen, \& Vähämaa, 2010; Lai, Srinidhi, Gul, \& Tsui, 2017). Lai et al. (2017) find that the positive impact of female directors on audit fees is robust to an alternative audit quality proxy, namely, industry specialist audit firm. Although they adopt industry specialist audit firms to compare their audit fee results, this approach is insufficient, as Aobdia (2019) finds no association between industry specialist audit firms and practitioners' assessment of audit quality. In contrast, Ittonen et al. (2010) find a negative association between the proportion of

\footnotetext{
${ }^{1}$ Aobdia (2019) evidences that three audit quality proxies (audit fees, meeting or beating the zero earnings benchmark and financial restatements) capture a distinct dimension of practitioners' audit quality assessments.
} 
female directors on audit committees and audit fees, leading to inconclusive evidence ${ }^{2}$. Given that no study utilises the propensity to meet or beat the zero earnings benchmark as an audit quality measure, we are unsure about the monitoring effectiveness of female directors on audit committees. Thus, the present literature cannot be deemed sufficient to conclude an association between female directors on audit committees and audit quality. Therefore, we assess the relation between female directors on audit committees and audit quality using both audit fees and meet or beat the zero earnings benchmark as audit quality proxies.

Financial expertise plays a vital role in the effectiveness of audit committees because a financial expert possesses more significant knowledge of financial statements (Bilal, Chen, \& Komal, 2018; Tanyi \& Smith, 2015). Regulators are, however, uncertain on the type of financial expertise considered most effective in monitoring financial reports. The United States (US) and the UK did initiate steps to consider only accounting experts as financial experts but, after receiving feedback from stakeholders, concluded that both accounting experts and nonaccounting financial experts are appropriate for complying with the requirement to include a financial expert on an audit committee (FRC, 2015; Ghafran \& O'Sullivan, 2017; Lee \& Park, 2018). The empirical research provides mixed findings on whether only accounting experts on audit committees perform an oversight function (Dhaliwal et al., 2010; Krishnan \& Visvanathan, 2008; Krishnan \& Visvanathan, 2009), while a competing argument prevails that non-accounting experts on audit committees are also effective (Ghafran \& O'Sullivan, 2017; Goh, 2009; Badolato, Donelson, \& Ege, 2014), warranting further investigation.

We use UK companies listed on the stock market to examine our research questions, because the litigation environment of the US is likely to be more stringent than the UK

\footnotetext{
${ }^{2}$ A positive association between female directors on audit committees and audit fees could indicate additional monitoring of female directors (Aldamen et al., 2018; Lai et al., 2017) while the negative relationship between female directors on audit committees and audit fees may stem from limited communication and greater conflicts due to the presence of diverse members on the audit committees (Ittonen et al., 2010).
} 
(Khurana \& Raman, 2004; Wu, Hsu, \& Haslam, 2016), as Seetharaman, Gul, and Lynn (2002) posit that class action suits are more prevalent in the US. Therefore, the better monitoring efforts of audit committee mechanisms are unlikely to be attributed to a highly litigious environment if the study is conducted in the UK. As a result, adopting the UK as our research setting may enhance the generalizability of findings (Wu et al., 2016). Moreover, Ghafran and O'Sullivan (2017) indicate that the UK follows comply or explain corporate governance regime. Hence, the UK context allows more variation in gender diversity practices, as the UK firms are not obligated to follow corporate governance policies. Our findings evidence that a total of $22 \%$ of audit committee members are female, and the number of accounting expert female directors (average 4\%) is relatively lower than non-accounting expert female directors (average 10\%), indicating a variation in financial expertise.

This study offers multiple contributions. First, our findings establish an association between female directors on audit committees and audit in the UK. Second, this study finds that female accounting experts on audit committees are significantly and positively associated with audit quality, while female non-accounting experts on audit committees are insignificantly associated with audit quality. Thus, Zalata et al.'s (2018) finding that female financial experts on audit committees enhance financial reporting monitoring, may stem from female financial experts with accounting expertise, while Ittonen et al.'s (2010) evidence that female financial experts on audit committees are insignificantly associated with financial reporting oversight, may originate from female financial experts with non-accounting expertise. Third, our study offers a more in-depth analysis of male financial experts on audit committees by segregating them into accounting and non-accounting experts. As we evidence that both male accounting and male non-accounting experts on the audit committee are insignificantly associated with audit quality, we offer further evidence on the effectiveness of male financial experts. 
The remainder of the paper is organized as follows. Section 2 presents the hypotheses of the study. The data and method of the study are thoroughly discussed in Section 3. In Section 4, we present and discuss the results. Finally, we conclude this study in Section 5.

\section{Hypotheses development}

Females may be more sensitive to ethics (Krishnan \& Parsons, 2008; Zalata et al., 2018), given that they are likely to be more considerate due to distinct socialisation (Lund, 2008; Owhoso, 2002; Srinidhi et al., 2011). Empirically, Bernardi, Bosco, and Columb (2009) find that female directors are positively linked with the firm being regarded as ethical. Similarly, Bernardi and Arnold (1997) substantiate that female managers depict higher moral development than male managers, suggesting that female directors are not expected to be involved in manipulating financial reports for personal gain (Krishnan \& Parsons, 2008; Srinidhi et al., 2011; Zalata et al., 2018).

Female directors are unlikely to be associated with an all-male network, which enhances independence (Adams \& Ferreria, 2009; Srinidhi et al., 2011; Zalata et al., 2018). Therefore, women directors are likely to be in a better position to question the decisions of other directors (Lai et al., 2017; Srinidhi et al., 2011). Moreover, females may demonstrate less overconfidence (Huang \& Kisgen, 2013; Ittonen \& Peni, 2012) and are more likely to be riskaverse (Garcia-Blandon, Argilés-Bosch, \& Ravenda, 2019; Ittonen, Vähämaa, \& Vähämaa, 2013), which is expected to enhance the level of monitoring (Lai et al., 2017; Srinidhi et al.,

2011). Empirically, studies show that female directors on an audit committee are likely to modify audit opinions (Pucheta-Martínez, Bel-Oms, \& Olcina-Sempere, 2016), reduce earnings management (Gavious Segev, \& Yosef, 2012; Srinidhi et al., 2011; Thiruvadi \& Huang, 2011; Zalata et al., 2018), and increase audit fees (Aldamen et al., 2018; Lai et al., 2017). 
On the other hand, as per social identity theory, directors are likely to develop associations with other directors in their own social category; thus, the presence of diverse members may have a negative impact on group communication (Jehn, Northcraft, \& Neale, 1999). Therefore, given that female directors induce diversity (Adams \& Ferreira, 2009), their inclusion on audit committees may result in more conflicts and a lack of communication (Jehn et al., 1999; Ittonen et al., 2010). Ittonen et al. (2010) find a negative association between the proportion of female directors on the audit committee and audit fees. In addition, Sun, Liu, and Lan (2011) find no link between female directors on audit committees and discretionary accruals.

Following the conflicting findings on the association between female directors on audit committees and audit quality, we propose the following hypothesis:

\section{$H_{1 .}$ Female directors on audit committees are significantly associated with audit quality.}

Agency theory is unlikely to be sufficient to explain a clear link between directors and their impact on organisations (Carter, D’Souza, Simkins, \& Simpson, 2003; Gull, Nekhili, Nagati, \& Chtioui, 2018). The theoretical framework proposed by Hillman and Dalziel (2003) emphasises a consideration of both agency theory and resource dependence theory when examining directors' effectiveness, suggesting that the effectiveness of female and male financial experts on audit committees may depend on the type of financial expertise possessed by individual directors themselves.

Accounting experts are pivotal in the monitoring of financial reports, given the sophisticated accounting involved in the financial statements (DeFond, Hann, \& $\mathrm{Hu}, 2005$; Dhaliwal et al., 2010; Kim, Kwak, Lim, \& Yu, 2017). Therefore, members with accounting or auditing know-how are more likely to be in a better position to question managers and auditors 
(Dhaliwal et al., 2010) and review management's response to the audit adjustments proposed by the auditors (DeFond et al., 2005). Similarly, Krishnan and Visvanathan (2008) posit that the competency of accounting experts enables them to evaluate provisions concerning warranties and lawsuits. Thus, they may be able to appropriately assess areas where judgments are involved (DeFond et al., 2005) and therefore increase audit quality.

Further, accounting experts might be considered to have more responsibility for monitoring financial reports, given their enhanced accounting knowledge; hence, they could be exposed to more significant reputational loss due to poor financial reporting, which may motivate accounting experts to intensify the monitoring of financial reports (Kim et al., 2017). Lee and Park (2018) substantiate that accounting experts on audit committees restrict managers in manipulating the tone of the MD\&A (management discussion and analysis) sections of financial reports. Multiple studies provide evidence of the better financial reporting oversight of accounting experts on audit committees. Krishnan and Visvanathan (2008) find that accounting experts on audit committees are positively associated with accounting conservatism. Similarly, Dhaliwal et al. (2010) report that accounting experts on audit committees increase accruals quality. DeFond et al. (2005) evidence that accounting experts on audit committees are associated with a positive market reaction. Also, Cohen, Hoitash, Krishnamoorthy, and Wright (2014), and Kim et al. (2017), report a positive association between the presence of accounting experts on audit committees and audit fees. As a result, we propose that female and male accounting experts on audit committees are likely to be positively associated with the monitoring of financial reports and thereby higher audit quality:

$H_{2 a}$. Female accounting experts on audit committees are positively associated with audit quality. 
$H_{2 b .}$ Male accounting experts on audit committees are positively associated with audit quality.

Hoitash, Hoitash and Bedard (2009) posit that non-accounting financial experts are less directly involved in financial reports. Thus, they may not have the requisite knowledge for monitoring financial statements (DeFond et al., 2005; Kim et al., 2017). As a result, nonaccounting experts on audit committees may diminish the effectiveness of audit committees. Naiker and Sharma (2009) substantiate that firms with non-accounting expertise on their audit committees are more likely to experience internal control deficiencies. Krishnan and Visvanathan (2009) find that non-accounting experts on audit committees are insignificantly associated with audit fees. Similarly, Dhaliwal et al. (2010) and Krishnan and Visvanathan (2008) substantiate that non-accounting experts on audit committees are insignificantly associated with accruals quality.

However, Ghafran and O’Sullivan (2017) contend that non-accounting (finance and supervisory) financial experts may acknowledge the lack of accounting competence and thus demand extensive audit work. Additionally, they may possess relatively more industry knowledge, which can add value to audit committees' monitoring capacity (Dhaliwal et al., 2010). For example, industry knowledge may be crucial for appropriately assessing warranty provisions (Cohen et al., 2014).

Supervisory experts may improve financial reporting quality due to their experience in supervising individuals with financial reporting duties (Naiker \& Sharma, 2009). Regarding finance experts, Lee and Park (2018) suggest that they are competent in analysing financial reports because they may have developed these skills. Dhaliwal et al. (2010) also hold a similar viewpoint and contend that finance experts are competent in forecasting earnings and evaluating mergers and acquisitions, which enables them to possess greater knowledge about 
the wide range of factors affecting firms and are thereby in a better position to assess whether financial reports depict the reality. This suggests that non-accounting (finance and supervisory) financial experts on audit committees are likely to improve audit quality.

Ghafran and O'Sullivan (2017) report that non-accounting experts on audit committees increase audit fees. Further, Goh (2009) finds that supervisory expertise on audit committees is positively related to the timely remediation of internal control weaknesses. Moreover, Xie, Davidson, and DaDalt (2003) evidence that investment bankers on audit committees reduce earnings management.

Due to the opposing views on the monitoring effectiveness of non-accounting experts on audit committees, we do not predict the direction of the hypotheses on female and male nonaccounting (finance and supervisory) experts:

$H_{3 a}$. Female finance experts (non-accounting financial experts) on audit committees are significantly associated with audit quality.

$H_{3 b .}$ Male finance experts (non-accounting financial experts) on audit committees are significantly associated with audit quality.

$H_{4 a}$. Female supervisory experts (non-accounting financial experts) on audit committees are significantly associated with audit quality.

$H_{4 b .}$ Male supervisory experts (non-accounting financial experts) on audit committees are significantly associated with audit quality.

\section{Methodology}

\subsection{Sample}

This study focuses on all non-financial firms on the FTSE 350 index from 2009 to 2017. The FTSE 350 index is chosen because it consists of large as well as small firms (Lueg, Punda, \& 
Burkert, 2014; Zaman, Hudaib, \& Haniffa, 2011), and because Lueg et al. (2014) contend that it ensures greater data availability. Non-financial firms are excluded because they have distinct regulatory and reporting requirements (Ghafran \& O'Sullivan, 2017; Lueg et al., 2014; Zalata et al., 2018). Further, only firms that were part of the FTSE 350 index from 2009 to 2017 are considered, given that the UK corporate governance regulation differentiates between firms on the FTSE 350 index and other firms listed in the UK; for example, it implements a less stringent requirement related to independent directors for non-FTSE 350 firms (Ghafran \& O'Sullivan, 2017).

Corporate governance data was manually collected from annual reports. Regarding financial characteristics, data was collected from the FAME database with the exception of location of the auditor, subsidiaries, market value of equity and annual market price return. Auditor's location and the number of subsidiaries were obtained from annual reports while the market value of equity and annual market price return were collected from Datastream. Data for ascertaining audit fees and meeting or beating the zero earnings benchmark was collected from the FAME database. Firms' annual reports were downloaded from their respective websites, while GICS in the Osiris database was utilised for identifying the industry in which the firm operates. The restrictions above and missing information reduce the firm-year observations to 770 (761) for the audit fee model related to female directors on audit committees (female and male financial experts on audit committees). Further, in relation to our meeting or beating the zero earnings benchmark, the final sample comprises 1130 (1119) for female directors on audit committees (female and male financial experts on audit committees) after taking into account the aforementioned data restrictions and missing information. These sample sizes are in line with other audit committee studies (Aldamen et al., 2018; Kusnadi, Leong, Suwardy, \& Wang, 2016).

\subsection{Measurement of female directors, financial experts and audit quality}




\subsubsection{Female directors}

Female directors on audit committees are ascertained as the proportion of female directors on the audit committee (Gavious et al., 2012; Zalata et al., 2018).

\subsubsection{Types of financial expertise}

We adopt Dhaliwal et al. (2010), Ghafran and O'Sullivan (2017, p. 584), and Lee and Park (2018), in segregating the financial expertise of the female and male audit committee members into three categories, namely accounting expertise (held or hold a position directly related to accounting and auditing, such as chartered accountants, chief financial officers, chief accounting officers, controllers and auditors), finance expertise (experience involving investment banking, financial analysis or any other position related to financial management), and supervisory expertise (chief executive officers and company presidents).

\subsubsection{Auditfees}

As discussed in the introduction, Aobdia (2019) contends that three different proxies capture a distinct dimension of the practitioners' perspective of audit quality. Given that the audit committees do not directly influence financial restatements (Lai et al., 2017), audit fees and meeting or beating the zero earnings benchmark are the two most appropriate audit quality proxies for examining the link between female directors on audit committees and audit quality. Therefore, we utilise two measures of audit quality: audit fees and meeting or beating the zero earnings benchmark. We use audit fees to address our research question and then examine our results in terms of meeting or beating the zero earnings benchmark.

Audit effort is likely to depict audit fees and, therefore, the higher the audit fees the higher the audit quality (Ghafran \& O’Sullivan, 2017; Goodwin-Stewart \& Kent, 2006). This study adopts the following audit fee models to assess whether female directors, female financial experts and male financial experts on audit committees are associated with audit fees: 
audfee $=\beta_{0}+\beta_{1}$ acfem $+\beta_{2}$ acind $+\beta_{3}$ acsize $+\beta_{4}$ acmeet $+\beta_{5}$ boardind $+\beta_{6}$ nonauditfee + $\beta_{7 \text { size }}+\beta_{8 \text { stock }}+\beta_{9}$ debt $+\beta_{10 l o n d o n}+\beta_{11 \text { subsidiary }}+\beta_{12 \text { roa }}+I N D+Y E+\varepsilon \quad \ldots$ (1a) audfee $=\beta_{0}+\beta_{1 \text { femacc }}+\beta_{2}$ femfinance $+\beta_{3}$ femsuper $+\beta_{4 \text { mlacc }}+\beta_{5 \text { mlfinance }}+\beta_{6}$ mlsuper $+\beta_{7}$ acind $+\beta_{8 \text { acsize }}+\beta_{9}$ acmeet $+\beta_{10 \text { boardind }}+\beta_{11 \text { nonauditfee }}+\beta_{12 \text { size }}+\beta_{13 \text { stock }}+$ $\beta_{14 d e b t}+\beta_{15 l o n d o n}+\beta_{16 \text { subsidiary }}+\beta_{17}$ roa $+I N D+Y E+\varepsilon$ $\ldots(1 b)$

All the above variables are defined in Table 1. Ghafran and O'Sullivan (2017) select their control variables in their audit fee model based on the prior UK research that finds significant audit fee determinants, as they argue that there is considerable literature on factors affecting audit fees. Therefore, we follow Ghafran and O'Sullivan (2017) in utilising the control variables related to our audit fee models.

Given that the large size of the audit committee can either be effective due to a variety of directors' experiences (Zalata et al., 2018), or likely to cause the members to neglect responsibility (Kent \& Stewart, 2008; Vafeas, 2005), we do not predict the direction of the link between audit committee size and audit fees. Moreover, due to the lack of familiarity of independent directors with management (Zaman et al., 2011), independent directors and audit committee independence are predicted to be positively associated with audit fees. Further, greater audit issues are likely to be identified with more audit committee meetings (Zaman et al., 2011) and are thus expected to be positively associated with audit fees.

In relation to control variables pertaining to firm characteristics, given the analysts' scrutiny of large firms' performance, these firms may practice earnings manipulation (Chih, Shen \& Kang, 2008) and are likely to have a positive association with audit fees due to the high audit risk. Moreover, the greater the complexity involved in the audit, the higher the audit effort (Zaman et al., 2011), which may increase audit fees. Further, a higher proportion of receivables 
and inventory balances depict enhanced audit effort due to more balance confirmations and site visits respectively (Lai et al., 2017), translating into higher audit fees.

Additionally, a firm's poor profitability position is likely to be indicative of higher audit risk (Ghafran \& O'Sullivan, 2017), so a negative association is predicted between profitability and audit fees. Furthermore, a positive association between London-based auditors and audit fees is predicted, as being in London entails a high living cost (Clatworthy \& Peel, 2007). Also, as per Ezzamel, Gwilliam, and Holland (1996), firms facing non-typical issues require nonaudit services and also incur high audit fees. Thus, non-audit fees and audit fees are predicted to be positively associated.

Measurement of the control variables follows prior literature: proportion of independent directors on the board (independent directors), number of audit committee members (audit committee size), number of audit committee meetings (audit committee meetings), proportion of independent directors on the audit committee (audit committee independence), log of number of subsidiaries (firm's complexity), log of total assets (firm size), proportion of inventories to total assets and proportion of receivables to total assets (inventory and receivables), return on assets (profitability), log of non-audit fees (non-audit fees), and dummy variable of 1 if the auditor is London-based, otherwise 0 (London-based auditor) (Ghafran \& O’Sullivan, 2017).

\subsubsection{Meeting or beating the zero earnings benchmark}

This study also utilises the propensity to meet or beat the zero earnings benchmark as an audit quality proxy. Firms may manipulate earnings to meet or beat the zero earnings benchmark in order to avoid a negative impact on their market value (Srinidhi et al., 2011; Tanyi \& Smith, 2015). Graham, Harvey, and Rajgopal (2005) contend that if a firm is unable to meet the earnings benchmark, then the market perceives it as a sign of poor prospects and thus reduces 
the firm's market price. Therefore, according to Srinidhi et al. (2011), post-managed earnings of just above zero are likely to be linked to earnings manipulation rather than to an actual increase in performance. As the propensity to meet or beat the zero earnings benchmark is likely to depict earnings management (DeFond \& Zhang, 2014; Srinidhi et al., 2011) and better auditing is expected to mitigate earnings management (Becker, DeFond, Jiambalvo, \& Subramanyam, 1998; Chen, Chen, Lobo, \& Wang, 2011; Francis, Maydew, \& Sparks, 1999), DeFond and Zhang (2014) argue that meeting or beating the zero earnings benchmark captures audit quality.

We adopt the following meet or beat the zero earnings benchmark model to test its association with female directors, female financial experts and male financial experts on audit committees:

meetbeat $=\beta_{0}+\beta_{1}$ acfem $+\beta_{2}$ acind $+\beta_{3}$ acsize $+\beta_{4}$ acmeet $+\beta_{5}$ boardind $+\beta_{6 s i z e}+$ $\beta_{\text {7returngrow }}+\beta_{\text {glev }}+\beta_{9 \text { salegrow }}+\beta_{10 m t b}+I N D+Y E+\varepsilon \quad \ldots(2 a)$

meetbeat $=\beta_{0}+\beta_{1}$ femacc $+\beta_{2}$ femfinance $+\beta_{3}$ femsuper $+\beta_{4}$ mlacc $+\beta_{5}$ mlfinance $+\beta_{6}$ mlsuper $+\beta_{7}$ acind $+\beta_{8}$ acsize $+\beta_{9}$ acmeet $+\beta_{10 \text { boardind }}+\beta_{11 \text { size }}+\beta_{12}$ returngrow $+\beta_{13 l e v}+$ $\beta_{14 \text { salegrow }}+\beta_{15 m t b}+I N D+Y E+\varepsilon \quad \ldots(2 b)$

All the variables are defined in Table 1. In line with Carey and Simnett (2006), Francis and Yu (2009), and Tanyi and Smith (2015), the propensity to meet or beat the zero earnings benchmark is ascertained as 1 if the return on assets is between 0 and 0.02 , otherwise 0 . Therefore, as the value of 1 is indicative of earnings manipulation, a negative sign in our main variables (female directors and types of female and male financial experts on the audit committee) will suggest higher audit quality.

Control variables related to corporate governance are the same as in the audit fee model; however, the sign expected in meeting or beating the zero earnings benchmark model is 
opposite to what is expected in the audit fee model, as lower values in the meeting or beating the zero earnings benchmark variable are suggestive of better audit quality. This study adopts control variables for the financial characteristics (firm size, financial condition, and firm growth) from Arun, Almahrog, and Aribi (2015). As large firms are under higher pressure to perform, more earnings manipulation can be expected (Chih et al., 2008). Firms with either higher leverage or lower performance demonstrate poor financial condition and, hence, are more likely to manage earnings (Ittonen et al., 2013; Zalata et al., 2018). Ittonen et al. (2013) point out that growing firms are less transparent. Thus, growing firms are expected to be more prone to earnings management (Arun et al., 2015; Chih et al., 2008). Following Arun et al. (2015), firm size is the natural log of total assets, leverage is ascertained by determining the proportion of total liabilities to total assets and growth is determined as annual growth in sales and market-to-book ratio. Further, performance is ascertained through annual market return (Srinidhi et al., 2011).

\section{Results analysis}

\subsection{Descriptive statistics and correlation analysis}

Table 2 (Panel A) presents the descriptive statistics. It shows that the average proportion of female directors on audit committees is around $22 \%$ in our sample. When compared to the value (12\%) found by Zalata et al. (2018) in the US, it shows a greater presence of female directors on audit committees in the UK. This is likely to reflect the increasing pressure within the UK to increase female directors (Department of Business, Innovation \& Skills, 2011). These descriptive statistics also show that the female (male) accounting experts on audit committees comprise $3.54 \%$ (34.37) of our sample. Further, we find that the female (male) audit committee members with finance and supervisory expertise comprise 10\% (17.90) and $3.58 \%$ (14.55) respectively in our sample. These descriptive statistics suggest a greater 
presence of male financial experts than female financial experts, which is in line with Zalata et al. (2018).

Table 2 (Panel B) presents the mean difference test for samples with and without female directors on audit committees. It shows that firms with female directors on audit committees have higher audit fees and a lower propensity to meet or beat the zero earnings benchmark than those firms with no female directors on audit committees, in line with our expectations. Moreover, compared to firms without any female presence on the audit committee, there are more audit committee meetings held in firms with at least one female on the audit committee, which is consistent with Thiruvadi (2012). Additionally, similar to Aldamen et al. (2018), firms that include female directors on audit committees are larger in size.

Table 3 presents the correlation matrix. It reveals a positive (negative) and significant correlation between female directors on audit committees and audit fees (meeting or beating the zero earnings benchmark). Moreover, there is also a positive and significant correlation between female accounting and non-accounting (finance) experts on audit committees and audit fees. However, this analysis does not control for other variables in the models and, therefore, the regression analysis presented below is a more appropriate procedure for answering our research questions. Further, there are unlikely to be problems arising from multicollinearity as the variance inflation factors (VIF) values are considerably below 10 in our main models (maximum VIF value is 2.93) (Bose, Podder, \& Biswas, 2017; Jackling \& Johl, 2009).

\subsection{Regression analysis}

Given that firms in the sample are present in multiple years, time-series dependence may cause a particular firm's residuals to be correlated over the years (Peterson, 2009), which is likely to introduce bias in the standard errors (Ghafran \& O'Sullivan, 2017). Following Ghafran and 
O’Sullivan (2017) and Hassanein and Hussainey (2015), this study addresses this problem by clustering the standard errors at the firm level. Also, cross-sectional dependence may lead to a particular year's residuals being correlated across firms (Peterson, 2009), which is addressed through introducing year dummies in line with Hassanein and Hussainey (2015).

Column 1 of Table 4 shows a positive and significant association between female directors on audit committees and audit fees. Column 2 of Table 4 reveals that female accounting experts on audit committees are significantly and positively associated with audit fees. Further, we find no significant association between female non-accounting (finance and supervisory) experts on audit committees and audit fees. This study also finds that male accounting and male non-accounting experts on audit committees are insignificantly associated with audit fees. However, these results also need to be examined using the propensity to meet or beat the zero earnings benchmark as an additional audit quality proxy.

Consistent with this study's expectations, the study finds that firm size, audit complexity, receivables and proportion of independent directors are significantly and positively associated with audit fees. The study also shows that both London-based auditors and non-audit fees have a positive and significant association with audit fees, as predicted. In addition, a negative and significant relation between return on assets and audit fees also meets our prediction.

\subsection{Meet or beat the zero earnings benchmark}

Column 1 of Table 5 shows that there is a negative and significant association between female directors on audit committees and meeting or beating the zero earnings benchmark. This negative sign depicts a positive association between the audit committee mechanisms and audit quality. Thus, given our significant and positive association between female directors on audit 
committees and audit fees, we evidence that female directors on audit committees are positively and significantly related to audit quality; therefore, hypothesis 1 is accepted.

Column 2 of Table 5 reports that female accounting experts on audit committees are significantly and negatively associated with the propensity to meet or beat the zero earnings benchmark. Considering our significant and positive association between female accounting experts on audit committees and audit fees, our study substantiates that female accounting experts have a significant and positive association with audit quality. Moreover, similar to our audit fee model, we find an insignificant association between female non-accounting experts and meeting or beating the zero earnings benchmark. Therefore, hypothesis $2 \mathrm{a}$ is supported while these findings do not support hypotheses $3 \mathrm{a}$ and $4 \mathrm{a}$. Additionally, both male accounting and male non-accounting experts are insignificantly associated with the propensity to meet or beat the zero earnings benchmark. As a result, hypotheses $2 b, 3 b$ and $4 b$ are not supported. Several of our control variables are significant. Audit committee independence, audit committee meetings, firm size and firm's financial condition are significantly associated with meeting or beating the zero earnings benchmark and are in line with our predictions.

\subsection{Robustness analysis}

In order to ascertain the robustness of our finding pertaining to the positive link between female accounting experts on audit committees and audit quality, we conduct three further tests. First, we adopt another measure of ascertaining female accounting on audit committees (here, we utilise a dummy variable of 1 if there is at least one female audit committee member with accounting expertise, otherwise 0). Column 1 of Table 6 (audit fee model) and Column 1 of Table 7 (meeting or beating the zero earnings benchmark model) reveal that our findings are consistent with another proxy of female accounting experts on audit committees. 
Third, following Aobdia (2019) and Castillo-Merino, Garcia-Blandon, and MartinezBlasco (2019), we employ another cut-off of 0 to 0.01 in our meeting or beating the zero earnings benchmark model. In Column 2 of Table 7, we still find a negative and significant relation between female accounting experts on audit committees and the propensity to meet or beat the zero earnings benchmark.

\subsection{Endogeneity}

Although we find that there is a positive association between female accounting experts on audit committees and audit quality, it is essential to address possible endogeneity bias. Hence, we adopt the propensity score matching methodology to mitigate these endogenous concerns. First, following Habib, Muhammadi, and Jiang (2017), Hardies, Breesch, and Branson (2015), Hooghiemstra, Hermes, Oxelheim, and Randøy (2019), Peel (2018), and Shipman, Swanquist, \& Whited (2017), all variables except the percentage of female accounting experts on the audit committee (the main variable in our case) are used to determine the probability of including female accounting experts on the audit committee. Hardies et al. (2015) contend that this approach is in line with the research on propensity score matching.

Secondly, matched pairs are ascertained, where a treated firm (with female accounting experts present on the audit committee) is matched with a control firm (without any female accounting experts present on the audit committee) with the closest propensity score to the treated firm (nearest neighbour matching) (Lai et al., 2017; Peel, 2018). In this step, the matching is performed without replacement, where control firms are matched to treated firms only once, as Shipman et al. (2017) posit that this procedure is standard in accountancy research. Moreover, as per Gull et al. (2018) and Hooghiemstra et al. (2019), a calliper distance (the maximum difference in the propensity scores of treated and control firms) of 0.01 is also implemented to enhance the quality of the matching. Finally, regression is conducted on the 
matched sample; this last step, according to Peel (2018), addresses any remaining differences in observable characteristics between matched and control firms and also entails a doubly robust approach in which "if either the matching or the parametric model is correct, but not necessarily both, causal estimates will still be consistent" (p. 175).

Tables A.1 (audit fees) and A.2 (meeting or beating the zero earnings benchmark) show the similarity between the treated and control firms, given that no observable firm characteristic is significant, thus suggesting successful matching (Habib et al., 2017; Peel, 2018). This shows that the treated and control firms are similar concerning the firm characteristics observed, so any effect on the dependent variable (audit quality, in this case) arises due to the variable of interest (female accounting experts on audit committees, in this study) (Habib et al., 2017; Peel, 2018). Column 2 of Table 6 (audit fees) and Column 3 of Table 7 (meeting or beating the zero earnings benchmark) present the regression analysis on the matched sample and indicates that female accounting experts on audit committees are positively and significantly associated with audit quality, given that they are positively linked with audit fees and negatively related with meeting or beating the zero earnings benchmark. Overall, propensity score matching analysis suggests that the finding associated with the positive relationship between female accounting experts on audit committees and audit quality is robust to any endogeneity bias.

\subsection{Tokenism}

A stream of research suggests that the influence on decision making requires the combined effort of multiple members - for example, at least two female directors may be necessary to influence decision making, whereas a singular female director may often be subject to tokenism (Erkut, Kramer, \& Konrad, 2008). Therefore, we conduct an additional regression analysis separating the firm-years which have at least two female directors in the audit committees $(\mathrm{n}=$ 
279). We find that our preliminary findings remain qualitatively unchanged, which suggest that tokenism has no impact on our findings.

\subsection{Omitted variable bias}

The concept of audit quality is not static and therefore identifying the determinants of audit quality is not conclusive. To mitigate the omitted-variable bias introduced by unobservable firm characteristics, we execute an analysis where we control for whether the firm experiences a going concern opinion. We also control financial reporting quality using discretionary accruals in the regression model, which are expected to control for time-invariant unobservable characteristics. We find that the preliminary results remain consistent and we therefore conclude that our findings are robust.

\section{Conclusion}

Corporate governance regulators' efforts to increase gender diversity in firms (Ali, $\mathrm{Ng}, \&$ Kulik, 2014; Lai et al., 2017; Srinidhi et al., 2011; Terjesen \& Sealy, 2016) indicate the importance of thoroughly examining whether female directors on audit committees improve audit quality. However, the previous literature on this aspect is not convincing as it fails to incorporate the practitioners' assessment of audit quality. Aobdia (2019) argues that it is important to consider the practitioners' views on audit quality, given that they possess more information about the audit and, hence, provide better judgment on audit quality. Thus, by incorporating practitioners' evaluations of audit quality in the audit quality measures, we provide more convincing evidence that female directors on audit committees act as an effective mechanism in improving audit quality.

Further, prior literature (Ittonen et al., 2010; Zalata et al., 2018) examining female financial experts on audit committees and financial reporting monitoring is mixed. We argue that this may be because the researchers did not segregate female financial experts into 
accounting or non-accounting expertise. Zalata et al. (2018) find that female financial experts on audit committees mitigate earnings management while Ittonen et al. (2010) evidence an insignificant association between female financial experts on audit committees and audit fees. Our findings seem to explain this conflicting evidence, as we find that the accounting expertise of female financial experts on audit committees is significantly and positively associated with audit quality while there is an insignificant association between non-accounting (finance and supervisory) female financial experts on audit committees and audit quality.

This study has several implications for regulators, policy-makers, firms and accountancy professionals. First, this study supports legislating to achieve a higher presence of female directors and suggests the beneficial effects of incorporating female directors. Also, our findings indicate that a female quota policy is likely to be useful only if female directors on audit committees have accounting expertise. Second, regulators in the US and the UK have made efforts to only consider audit committee members with accounting expertise as part of the requirement to include a financial expert on audit committees. However, they have been unable to implement this policy due to the concerns stemming from the rigidness of such a directive (FRC, 2015; Ghafran \& O’Sullivan, 2017; Lee \& Park, 2018). Our results suggest that policy-makers should emphasise the benefits of including accounting experts on audit committees to the stakeholders. Third, our study benefits managers who are attempting to enhance the audit quality of firms, as we find that firms experience an increase in audit quality if female directors with accounting expertise are present on the audit committee. Finally, this study's findings suggest a limited presence of female accounting experts on audit committees. As we substantiate here that female accounting experts positively influence audit quality, our study recommends the accountancy profession implement policies to attract more female members. These involve, for example, conducting seminars/conferences where female accountants are invited, devising sponsorship opportunities for females, and making efforts to 
reduce the gender pay gap for female accountants, which may inspire and motivate females to join the accounting profession.

Our study's findings should be considered with caution. Despite using multiple methodologies to mitigate any endogenous bias, we acknowledge that endogeneity might not have been completely addressed. Furthermore, our findings may not apply to other research settings with distinct cultures and institutions. Lastly, the finding of an insignificant association between female non-accounting experts and audit quality may be dependent on whether the experts possess other characteristics, such as additional directorships. Therefore, future researchers may study specific characteristics of female non-accounting experts on audit committees. 


\section{References}

Adams, R., \& Ferreira, D. (2009). Women in the boardroom and their impact on governance and performance. Journal of Financial Economics, 94(2), 291-309.

Aldamen, H., Hollindale, J., \& Ziegelmayer, J. L. (2018). Female audit committee members and their influence on audit fees. Accounting and Finance, 58(1), 57-89.

Ali, M., Ng, Y. L., \& Kulik, C. T. (2014). Board age and gender diversity: A test of competing linear and curvilinear predictions. Journal of Business Ethics, 125(3), 497-512.

Aobdia, D. (2019). Do practitioner assessments agree with academic proxies for audit quality? Evidence from PCAOB and internal inspections. Journal of Accounting and Economics, 67(1), 144-174.

Arun, T. G., Almahrog, Y. E., \& Aribi, Z. A. (2015). Female directors and earnings management: Evidence from UK companies. International Review of Financial Analysis, $39,137-146$.

Badolato, P., Donelson, D., Ege, M. (2014). Audit committee financial expertise and earnings management: The role of status. Journal of Accounting and Economics, 58(2-3), 208-230.

Becker, C., DeFond, M., Jiambalvo, J., \& Subramanyam, K. (1998). The effect of audit quality on earnings management. Contemporary Accounting Research, 15(1), 1-24.

Bédard, J., \& Gendron, Y. (2010). Strengthening the financial reporting system: Can audit committees deliver? International Journal of Auditing, 14(2), 174-210.

Bell, T., Causholli, M. \& Knechel, W. (2015). Audit firm tenure, non-audit services, and internal assessments of audit quality. Journal of Accounting Research, 53(3), 461-509.

Bernardi, R. A., Bosco, S. M., \& Columb, V. L. (2009). Does female representation on boards 
of directors associate with the 'most ethical companies' list? Corporate Reputation Review, 12(3), 270-280.

Bernardi, R., \& Arnold, D. (1997). An examination of moral development within public accounting by gender, staff level, and firm. Contemporary Accounting Research, 14(4), 653-668.

Bilal, Chen, S., \& Komal, B. (2018). Audit committee financial expertise and earnings quality: A meta-analysis. Journal of Business Research, 84, 253-270.

Bose, S., Podder, J., \& Biswas, K. (2017). Philanthropic giving, market-based performance and institutional ownership: Evidence from an emerging economy. British Accounting Review, 49(4), 429-444.

Carey, P., \& Simnett, R. (2006). Audit partner tenure and audit quality. Accounting Review, 81(3), 653-676.

Carter, D., Simkins, B., \& Simpson, W. (2003). Corporate governance, board diversity, and firm value. Financial Review, 38(1), 33-53.

Castillo-Merino, D., Garcia-Blandon, J., \& Martinez-Blasco, M. (2019). Auditor independence, current and future NAS fees and audit quality: Were European regulators right? European Accounting Review. https://doi.org/10.1080/09638180.2019.1577151

Chen, H., Chen, J., Lobo, G., \& Wang, Y. (2011). Effects of audit quality on earnings management and cost of equity capital: Evidence from China. Contemporary Accounting Research, 28(3), 892-925.

Chih, H., Shen, C., \& Kang, F. (2008). Corporate social responsibility, investor protection, and earnings management: Some international evidence. Journal of Business Ethics, 79(1-2), 179-198. 
Clatworthy, M. A., \& Peel, M. J. (2007). The effect of corporate status on external audit fees: Evidence from the UK. Journal of Business Finance and Accounting, 34(1-2), 169-201.

Cohen, J., Hoitash, U., Krishnamoorthy, G., \& Wright, A. (2014). The effect of audit committee industry expertise on monitoring the financial reporting process. Accounting Review, 89(1), 243-273.

DeFond, M., \& Zhang, J. (2014). A review of archival auditing research. Journal of Accounting and Economics, 58(2-3), 275-326.

DeFond, M., Hann, R., \& Hu, X. (2005). Does the market value financial expertise on audit committees of boards of directors? Journal of Accounting Research, 43(2), 153-193.

Department for Business, Innovation \& Skills (2011). Women on boards. Available at: https://www.gov.uk/government/publications/women-on-boards-review Accessed 24.07.2018.

Department for Business, Innovation \& Skills (2015). Women on boards: 5 year summary (Davies review). Available at: https://www.gov.uk/government/publications/women-onboards-5-year-summary-davies-review Accessed 9.12.2019

Dhaliwal, D., Naiker, V., \& Navissi, F. (2010). The association between accruals quality and the characteristics of accounting experts and mix of expertise on audit committees. Contemporary Accounting Research, 27(3), 787-827.

Erkut, S., Kramer, V. W., \& Konrad, A. M. (2008). Critical mass: Does the number of women on a corporate board make a difference? In S. Vinnicombe, V. Singh, R. Burke, D. Bilimoria, \& M. Huse (Eds.), Women on corporate board of directors: International research and practice (pp. 222-232). Cheltenham: Edward Elgar.

Ezzamel, M., Gwilliam, D. R., \& Holland, K. M. (1996). Some empirical evidence from 
publicly quoted UK companies on the relationship between the pricing of audit and nonaudit services. Accounting and Business Research, 27(1), 3-16.

Financial Reporting Council (2015). Enhancing Confidence in Audit: Proposed Revisions to the Ethical Standard, Auditing Standards, UK Corporate Governance Code and Guidance on Audit Committees. Available at: https://www.frc.org.uk/getattachment/e7841adf-ca5b44e9-af1b-aa83cafeb5b9/;.aspx Accessed 30.04.2019.

Financial Reporting Council (2018). The UK Corporate Governance Code. Available at: https://www.frc.org.uk/getattachment/88bd8c45-50ea-4841-95b0-d2f4f48069a2/2018UK-Corporate-Governance-Code-FINAL.PDF Accessed 11.08.2018.

Francis, J., \& Yu, M. (2009). Big 4 office size and audit quality. The Accounting Review, 84(5), $1521-1552$.

Francis, J., Maydew, E., \& Sparks, H. (1999). The role of Big 6 auditors in the credible reporting of accruals. Auditing: A Journal of Practice \& Theory, 18(2), 17-34.

Garcia-Blandon, J., Argilés-Bosch, J. M., \& Ravenda, D. (2019). Is there a gender effect on the quality of audit services? Journal of Business Research, 96, 238-249.

Gavious, I., Segev, E., \& Yosef, R. (2012). Female directors and earnings management in hightechnology firms. Pacific Accounting Review, 24(1), 4-32.

Ghafran, C., \& O'Sullivan, N. (2017). The impact of audit committee expertise on audit quality: Evidence from UK audit fees. British Accounting Review, 49(6), 578-593.

Goh, B. (2009). Audit committees, boards of directors, and remediation of material weaknesses in internal control. Contemporary Accounting Research, 26(2), 549-579.

Goodwin-Stewart, J., \& Kent, P. (2006). Relation between external audit fees, audit committee characteristics and internal audit, Accounting and Finance, 46(3), 387-404. 
Graham, J., Harvey, C., \& Rajgopal., S. (2005). The economic implications of corporate financial reporting. Journal of Accounting and Economics, 40(1-3), 3-73.

Gull, A. A., Nekhili, M., Nagati, H., \& Chtioui, T. (2018). Beyond gender diversity: How specific attributes of female directors affect earnings management. British Accounting Review, 50(3), 255-274.

Habib, A., Muhammadi, A. H., \& Jiang, H. (2017). Political connections, related party transactions, and auditor choice: Evidence from Indonesia. Journal of Contemporary Accounting and Economics, 13(1), 1-19.

Hardies, K., Breesch, D., \& Branson, J. (2015). The female audit fee premium. Auditing: A Journal of Practice \& Theory 34(4), 171-195.

Hassanein, A., \& Hussainey, K. (2015). Is forward-looking financial disclosure really informative? Evidence from UK narrative statements. International Review of Financial Analysis, 41, 52-61.

Hillman, A., \& Dalziel, T. (2003). Boards of directors and firm performance: Integrating agency and resource dependence perspectives. Academy of Management Review, 28(3), 383-396.

Hoitash, U., Hoitash, R., \& Bedard, J. (2009). Corporate governance and internal control over financial reporting: A comparison of regulatory regimes. Accounting Review, 84(3), 839867.

Hooghiemstra, R., Hermes, N., Oxelheim, L., \& Randøy, T. (2019). Strangers on the board: The impact of board internationalization on earnings management of Nordic firms. International Business Review, 28(1), 119-134.

Huang, J., \& Kisgen, D. (2013). Gender and corporate finance: Are male executives 
overconfident relative to female executives? Journal of Financial Economics, 108(3), 822-839.

Ittonen, K., \& Peni, E. (2012). Auditor's gender and audit fees. International Journal of Auditing, 16(1), 1-18.

Ittonen, K., Miettinen, J., \& Vähämaa, S. (2010). Does female representation in audit committees affect audit fees? Quarterly Journal of Finance and Accounting, 49(3-4), $113-139$.

Ittonen, K., Vahamaa, E., \& Vahamaa, S. (2013). Female auditors and accruals quality. Accounting Horizons, 27(2), 205-228.

Jackling, B., \& Johl, S. (2009). Board structure and firm performance: Evidence from India's top companies. Corporate Governance: An International Review, 17(4), 492-509.

Jehn, K., Northcraft, G., \& Neale, M. (1999). Why differences make a difference: A field study of diversity, conflict and performance in workgroups. Administrative Science Quarterly, 44(4), 741-763.

Kent, P., \& Stewart, J. (2008). Corporate governance and disclosures on the transition to International Financial Reporting Standards. Accounting \& Finance, 48(4), 649-671.

Khurana, I. K., \& Raman, K. K. (2004). Litigation risk and the financial reporting credibility of big 4 versus non-big 4 audits: Evidence from Anglo-American countries. The Accounting Review, 79(2), 473-495.

Kim, H., Kwak, B., Lim, Y., \& Yu, J. (2017). Audit committee accounting expertise, CEO power, and audit pricing. Asia-Pacific Journal of Accounting \& Economics, 24(3-4), 421439.

Krishnan, G., \& Parsons, L. (2008). Getting to the bottom line: An exploration of gender and 
earnings quality. Journal of Business Ethics, 78(1-2), 65-76.

Krishnan, G., \& Visvanathan, G. (2008). Does the SOX definition of an accounting expert matter? The association between audit committee directors' accounting expertise and accounting conservatism. Contemporary Accounting Research, 25(3), 827-857.

Krishnan, G., \& Visvanathan, G. (2009). Do auditors price audit committee's expertise? The case of accounting versus nonaccounting financial experts. Journal of Accounting, Auditing \& Finance, 24(1), 115-144.

Kusnadi, Y., Leong, K., Suwardy, T., \& Wang, J. (2016). Audit committees and financial reporting quality in Singapore. Journal of Business Ethics, 139(1), 197-214.

Lai, K. M. Y., Srinidhi, B., Gul, F. A., \& Tsui, J. S. L. (2017). Board gender diversity, auditor fees, and auditor choice. Contemporary Accounting Research, 34(3), 1681-1714.

Lee, J., \& Park, J. (2018). The impact of audit committee financial expertise on management discussion and analysis (MD\&A) tone. European Accounting Review 28(1), 129-150.

Lueg, R., Punda, P., \& Burkert, M. (2014). Does transition to IFRS substantially affect key financial ratios in shareholder-oriented common law regimes? Evidence from the UK. Advances in Accounting, 30(1), 241-250.

Lund, D. (2008). Gender differences in ethics judgment of marketing professionals in the United States. Journal of Business Ethics, 77(4), 501-515.

Naiker, V., \& Sharma, D. (2009). Former audit partners on the audit committee and internal control deficiencies. The Accounting Review, 84(2), 559-587

Owhoso, V. (2002). Mitigating gender-specific superior ethical sensitivity when assessing likelihood of fraud risk. Journal of Managerial Issues, 14(3), 360-374. 
Peel, M. (2018). Addressing unobserved selection bias in accounting studies: The bias minimization method. European Accounting Review, 27(1), 173-183.

Petersen, M. A. (2009). Estimating standard errors in finance panel data sets: Comparing approaches. Review of Financial Studies, 22(1), 435-480.

Pucheta-Martínez, M., Bel-Oms, I., \& Olcina-Sempere, G. (2016). Corporate governance, female directors and quality of financial information. Business Ethics: A European Review, 25(4), 363-385.

Securities Markets Association (2015). Finnish corporate governance code 2015. Available at: https://cgfinland.fi/wp-content/uploads/sites/6/2015/10/hallinnointikoodi-2015eng.pdf Accessed 9.12.2019

Seetharaman, A., Gul, F., \& Lynn. S. (2002). Litigation risk and audit fees: Evidence from UK firms cross-listed on US markets. Journal of Accounting and Economics, 33(1), 91-115.

Shipman, J. E., Swanquist, Q. T., \& Whited, R. L. (2017). Propensity score matching in accounting research. The Accounting Review, 92(1), 213-244.

Srinidhi, B., Gul, F. A., \& Tsui, J. (2011). Female directors and earnings quality. Contemporary Accounting Research, 28(5), 1610-1644.

Sun, J., Liu, G., \& Lan, G. (2011). Does female directorship on independent audit committees constrain earnings management? Journal of Business Ethics, 99(3), 369-382.

Swedish Corporate Governance Board (2016). The Swedish corporate governance code. Available at: http://www.corporategovernanceboard.se/UserFiles/Archive/496/The_Swedish_Corpora te_Governance_Code_1_December_2016.pdf

Tanyi, P. N., \& Smith, D. B. (2015). Busyness, expertise, and financial reporting quality of 
audit committee chairs and financial experts. Auditing: A Journal of Practice \& Theory, 34(2), 59-89.

Terjesen, S., \& Sealy, R. (2016). Board gender quotas: Exploring ethical tensions from a multitheoretical perspective. Business Ethics Quarterly, 26(1), 23-65.

Terjesen, S., Aguilera, R., \& Lorenz, R. (2015). Legislating a woman's seat on the board: Institutional factors driving gender quotas for boards of directors. Journal of Business Ethics, 128(2), 233-251.

Thiruvadi, S. (2012). Gender differences and audit committee diligence. Gender in Management: An International Journal, 27(6), 366-379.

Thiruvadi, S., \& Huang, H. (2011). Audit committee gender differences and earnings management. Gender in Management: An International Journal, 26(7), 483-498.

Vafeas, N. (2005). Audit committees, boards, and the quality of reported earnings. Contemporary Accounting Research, 22(4), 1093-1122.

Wahid, A. S. (2019). The effects and the mechanisms of board gender diversity: Evidence from financial manipulation. Journal of Business Ethics, 159(3), 705-725.

Wu, C. Y. H., Hsu, H. H., \& Haslam, J. (2016). Audit committees, non-audit services, and auditor reporting decisions prior to failure. British Accounting Review, 48(2), 240-256.

Xie, B., Davidson, W., \& Dadalt, P. (2003). Earnings management and corporate governance: The role of the board and the audit committee. Journal of Corporate Finance, 9(3), 295316.

Zalata, A. M., Tauringana, V., \& Tingbani, I. (2018). Audit committee financial expertise, gender, and earnings management: Does gender of the financial expert matter? International Review of Financial Analysis, 55, 170-183. 
Zaman, M., Hudaib, M., \& Haniffa, R. (2011). Corporate governance quality, audit fees and non-audit services fees. Journal of Business Finance and Accounting, 38(1-2), 165-197. 
Table 1: Variable definition

\begin{tabular}{|c|c|}
\hline Variables & Definition \\
\hline Audit fees (audfee) & Log of audit fees \\
\hline $\begin{array}{l}\text { Meeting or beating the zero earnings } \\
\text { benchmark (meetbeat) }\end{array}$ & 1 if return on assets is between $0-0.02$ otherwise 0 \\
\hline Female directors on audit committees (acfem) & Proportion of female directors on the audit committee \\
\hline $\begin{array}{l}\text { Female accounting experts on the audit } \\
\text { committee (femacc) }\end{array}$ & $\begin{array}{l}\text { Proportion of female accounting experts on the audit } \\
\text { committee }\end{array}$ \\
\hline $\begin{array}{l}\text { Female non-accounting (finance) experts on } \\
\text { the audit committee (femfinance) }\end{array}$ & $\begin{array}{l}\text { Proportion of female non-accounting (finance) experts on } \\
\text { the audit committee }\end{array}$ \\
\hline $\begin{array}{l}\text { Female non-accounting (supervisory) experts } \\
\text { on the audit committee (femsuper) }\end{array}$ & $\begin{array}{l}\text { Proportion of female non-accounting (supervisory) experts } \\
\text { on the audit committee }\end{array}$ \\
\hline $\begin{array}{l}\text { Male accounting experts on the audit } \\
\text { committee (mlacc) }\end{array}$ & $\begin{array}{l}\text { Proportion of male accounting experts on the audit } \\
\text { committee }\end{array}$ \\
\hline $\begin{array}{l}\text { Male non-accounting (finance) experts on the } \\
\text { audit committee (mlfinance) }\end{array}$ & $\begin{array}{l}\text { Proportion of male non-accounting (finance) experts on } \\
\text { the audit committee }\end{array}$ \\
\hline $\begin{array}{l}\text { Male non-accounting (supervisory) experts on } \\
\text { the audit committee (mlsuper) }\end{array}$ & $\begin{array}{l}\text { Proportion of male non-accounting (supervisory) experts } \\
\text { on the audit committee }\end{array}$ \\
\hline Audit committee size (acsize) & Number of audit committee members \\
\hline Audit committee meetings (acmeet) & Number of audit committee meetings \\
\hline Audit committee independence (acind) & $\begin{array}{l}\text { Proportion of independent directors on the audit } \\
\text { committee }\end{array}$ \\
\hline Board independence (boardind) & Proportion of independent directors on the board \\
\hline Firm size (size) & Log of total assets \\
\hline Inventory (stock) & Proportion of stock to total assets \\
\hline Receivables $(d e b t)$ & Proportion of receivables to total assets \\
\hline London-based auditor (london) & 1 if the auditor is based in London otherwise 0 \\
\hline Complexity (subsidiary) & Log of subsidiaries \\
\hline Profitability (roa) & Return on assets (proportion of net income to total assets) \\
\hline Non-audit fees (nonauditfees) & Log of non-audit fees \\
\hline Leverage $(l e v)$ & Proportion of liabilities to assets \\
\hline Sales growth (salegrow) & Annual sales growth \\
\hline Market-to-book ratio $(m t b)$ & $\begin{array}{l}\text { Proportion of market value of equity to book value of } \\
\text { equity }\end{array}$ \\
\hline Annual market price return (returngrow) & Annual market price growth \\
\hline $\begin{array}{l}\text { Alternative definition of female accounting } \\
\text { experts on audit committees (dumfemacc) }\end{array}$ & $\begin{array}{l}\text { Dummy variable of } 1 \text { if at least one female accounting } \\
\text { expert is present on the audit committee otherwise } 0\end{array}$ \\
\hline$I N D$ & Industry effects \\
\hline$Y E$ & Year effects \\
\hline
\end{tabular}


Table 2: Panel A Descriptive statistics

\begin{tabular}{lrrrr}
\hline Variable & Mean & $\begin{array}{r}\text { Standard } \\
\text { Deviation }\end{array}$ & Minimum & Maximum \\
\hline audfee & 7.140 & 1.320 & 1.099 & 10.589 \\
meetbeat & 0.066 & 0.248 & 0.000 & 1.000 \\
acfem & 0.218 & 0.187 & 0.000 & 1.000 \\
femacc & 0.035 & 0.094 & 0.000 & 0.667 \\
femfinance & 0.100 & 0.142 & 0.000 & 0.500 \\
femsuper & 0.036 & 0.092 & 0.000 & 0.400 \\
mlacc & 0.344 & 0.179 & 0.000 & 1.000 \\
mlfinance & 0.179 & 0.201 & 0.000 & 0.750 \\
mlsuper & 0.146 & 0.180 & 0.000 & 0.750 \\
acsize & 3.957 & 1.065 & 2.000 & 8.000 \\
acmeet & 4.536 & 1.688 & 1.000 & 15.000 \\
acind & 0.990 & 0.064 & 0.000 & 1.000 \\
boardind & 0.564 & 0.109 & 0.000 & 0.857 \\
nonauditfee & 6.313 & 1.374 & 1.099 & 9.864 \\
size & 15.073 & 1.463 & 12.140 & 19.621 \\
stock & 0.124 & 0.176 & 0.000 & 0.928 \\
debt & 0.105 & 0.087 & 0.000 & 0.660 \\
london & 0.762 & 0.426 & 0.000 & 1.000 \\
subsidiary & 2.834 & 1.027 & 0.000 & 6.031 \\
roa & 0.083 & 0.106 & -1.343 & 0.391 \\
returngrow & 0.130 & 0.423 & -0.961 & 3.818 \\
lev & 0.622 & 0.196 & 0.141 & 1.331 \\
salegrow & 0.064 & 0.218 & -0.740 & 3.639 \\
mtb & 2.979 & 13.195 & -123.612 & 147.540 \\
\hline All variables are & & & &
\end{tabular}


Table 2: Panel B Mean difference test

\begin{tabular}{lcccc}
\hline & acfem $=0$ & acfem $=1$ & Mean Difference & $t$-statistic \\
\hline audfee & 6.721 & 7.063 & $-0.342^{* * *}$ & -4.312 \\
meetbeat & 0.092 & 0.054 & $0.038^{* * *}$ & 3.122 \\
acsize & 3.364 & 4.187 & $-0.823^{* * *}$ & -14.211 \\
acmeet & 4.354 & 4.655 & $-0.301^{* *}$ & -2.025 \\
acind & 0.983 & 0.931 & $0.052^{*}$ & 1.714 \\
boardind & 0.534 & 0.583 & $-0.049^{* * *}$ & -6.601 \\
nonauditfee & 6.062 & 6.086 & -0.006 & -0.099 \\
size & 14.566 & 14.988 & $-0.422^{* * *}$ & 4.768 \\
stock & 0.108 & 0.122 & -0.014 & 1.218 \\
debt & 0.115 & 0.151 & $-0.036^{*}$ & 1.785 \\
london & 0.722 & 0.655 & $0.067^{* *}$ & 1.997 \\
subsidiary & 2.931 & 2.723 & $0.208^{* * *}$ & 3.219 \\
roa & 0.083 & 0.096 & -0.013 & -0.775 \\
returngrow & 0.127 & 0.115 & 0.012 & 0.337 \\
lev & 0.554 & 0.628 & $-0.074^{* * *}$ & -4.629 \\
salegrow & 0.082 & 0.064 & $0.018^{*}$ & 1.884 \\
mtb & 6.175 & 6.122 & 0.053 & 0.512 \\
\hline
\end{tabular}

This table presents differences in means between firms without a female director on audit committees and firms with at least one female director on the audit committee. All variables are defined in Table $1 .{ }^{* * *} p<0.01$, ** $p<0.05, * p<0.1$ 
Table 3: Correlation matrix

\begin{tabular}{|c|c|c|c|c|c|c|c|c|c|}
\hline & audfee & meetbeat & acfem & femacc & femfinance & femsuper & mlacc & mlfinance & mlsuper \\
\hline audfee & 1.000 & & & & & & & & \\
\hline meetbeat & 0.026 & 1.000 & & & & & & & \\
\hline acfem & $0.077 *$ & $-0.079 *$ & 1.000 & & & & & & \\
\hline femacc & $0.069 *$ & -0.035 & $0.393 *$ & 1.000 & & & & & \\
\hline femfinance & $0.102 *$ & 0.011 & $0.547 *$ & $-0.095 *$ & 1.000 & & & & \\
\hline femsuper & -0.022 & -0.036 & $0.323 *$ & $-0.107 *$ & $-0.105^{*}$ & 1.000 & & & \\
\hline mlacc & -0.047 & 0.033 & $-0.280^{*}$ & $-0.278 *$ & -0.032 & $-0.058 *$ & 1.000 & & \\
\hline mlfinance & -0.002 & 0.022 & $-0.216^{*}$ & 0.034 & $-0.229 *$ & $-0.085 *$ & $-0.352^{*}$ & 1.000 & \\
\hline mlsuper & 0.042 & 0.001 & $-0.287^{*}$ & $-0.139 *$ & $-0.142^{*}$ & $-0.088 *$ & $-0.157^{*}$ & $-0.320^{*}$ & 1.000 \\
\hline acind & $0.159 *$ & -0.044 & $0.080 *$ & 0.026 & 0.041 & $0.059 *$ & $-0.094^{*}$ & 0.039 & 0.024 \\
\hline acsize & $0.267 *$ & $-0.050^{*}$ & $0.270^{*}$ & $0.052 *$ & $0.168 *$ & $0.092 *$ & $-0.200^{*}$ & -0.045 & 0.02 \\
\hline acmeet & $0.412 *$ & -0.003 & $0.068 *$ & $0.048 *$ & $0.162 *$ & -0.045 & 0.042 & $0.087 *$ & $-0.068 *$ \\
\hline boardind & $0.509 *$ & -0.01 & $0.152 *$ & $0.105^{*}$ & $0.131 *$ & 0.02 & 0.046 & $-0.052 *$ & -0.016 \\
\hline nonauditfee & $0.728 *$ & 0.03 & $-0.056^{*}$ & -0.027 & 0.045 & $-0.134^{*}$ & 0.025 & $0.075^{*}$ & 0.023 \\
\hline size & $0.760 *$ & $0.054 *$ & $0.108 *$ & 0.017 & $0.185 *$ & 0.002 & 0.03 & 0.03 & -0.025 \\
\hline stock & $-0.272 *$ & -0.036 & $0.092 *$ & $0.078 *$ & -0.015 & -0.034 & -0.033 & $0.052 *$ & $-0.111 *$ \\
\hline$d e b t$ & 0.017 & -0.043 & -0.015 & $0.054 *$ & $-0.079 *$ & -0.026 & $-0.078 *$ & $-0.059 *$ & $0.141 *$ \\
\hline london & $0.385 *$ & $0.065^{*}$ & -0.016 & $0.063 *$ & $-0.094^{*}$ & $0.055^{*}$ & -0.02 & $0.107 *$ & -0.027 \\
\hline subsidiary & $0.466 *$ & -0.029 & -0.045 & $0.075 *$ & 0.009 & $-0.084 *$ & -0.011 & -0.047 & 0.026 \\
\hline roa & $-0.168 *$ & $-0.149 *$ & $0.049 *$ & $0.051 *$ & 0.019 & $-0.076^{*}$ & $0.064 *$ & -0.034 & -0.047 \\
\hline returngrow & $-0.049 *$ & $-0.086^{*}$ & -0.015 & 0.02 & $-0.064 *$ & -0.006 & -0.006 & 0.033 & -0.001 \\
\hline$l e v$ & $0.229 *$ & $0.048 *$ & $0.108 *$ & $0.097 *$ & $0.086 *$ & -0.021 & $-0.148 *$ & $-0.050^{*}$ & $0.054 *$ \\
\hline salegrow & $-0.078 *$ & $-0.052 *$ & $-0.060 *$ & -0.014 & $-0.057 *$ & -0.011 & 0.01 & $0.071 *$ & 0.011 \\
\hline$m t b$ & $-0.091 *$ & -0.02 & -0.001 & -0.011 & 0.007 & $0.059 *$ & $0.058 *$ & 0.036 & $-0.064 *$ \\
\hline
\end{tabular}


Table 3 (continued)

\begin{tabular}{|c|c|c|c|c|c|c|c|c|}
\hline & acind & acszie & acmeet & boardind & nonauditfee & size & stock & $d e b t$ \\
\hline acind & 1.000 & & & & & & & \\
\hline acsize & 0.021 & 1.000 & & & & & & \\
\hline acmeet & $0.010 *$ & $0.083 *$ & 1.000 & & & & & \\
\hline boardind & $0.344 *$ & $0.338^{*}$ & $0.392 *$ & 1.000 & & & & \\
\hline nonauditfee & $0.094 *$ & $0.207 *$ & $0.385^{*}$ & $0.403 *$ & 1.000 & & & \\
\hline size & $0.112 *$ & $0.215^{*}$ & $0.430 *$ & $0.494 *$ & $0.647 *$ & 1.000 & & \\
\hline stock & 0.036 & -0.034 & $-0.143 *$ & $-0.133^{*}$ & $-0.257 *$ & $-0.163^{*}$ & 1.000 & \\
\hline debt & 0.037 & $0.074^{*}$ & -0.034 & $-0.054^{*}$ & $-0.080 *$ & $-0.321^{*}$ & $-0.069 *$ & 1.000 \\
\hline london & $0.093 *$ & $0.184^{*}$ & $0.242 *$ & $0.307 *$ & $0.350 *$ & $0.379^{*}$ & 0.008 & $-0.182 *$ \\
\hline subsidiary & $0.146^{*}$ & $0.120^{*}$ & $0.149 *$ & $0.196^{*}$ & $0.271 *$ & $0.188^{*}$ & $-0.282 *$ & $0.227 *$ \\
\hline roa & 0.007 & 0.003 & $-0.081 *$ & -0.010 & $-0.141 *$ & $-0.233^{*}$ & $0.070^{*}$ & $0.203 *$ \\
\hline returngrow & -0.010 & 0.015 & $-0.062 *$ & -0.032 & -0.010 & $-0.068^{*}$ & $0.056^{*}$ & 0.017 \\
\hline lev & 0.043 & $0.075^{*}$ & 0.028 & $0.082 *$ & $0.158 *$ & $0.132 *$ & $-0.229 *$ & $0.099 *$ \\
\hline salegrow & 0.016 & 0.008 & $-0.060^{*}$ & -0.018 & -0.033 & $-0.048^{*}$ & 0.042 & -0.017 \\
\hline \multirow[t]{2}{*}{$m t b$} & 0.004 & $-0.055^{*}$ & 0.029 & 0.003 & $-0.165 *$ & $-0.166^{*}$ & -0.004 & $0.191 *$ \\
\hline & london & subsidiary & roa & returngrow & lev & salegrow & $m t b$ & \\
\hline london & 1.000 & & & & & & & \\
\hline subsidiary & $0.102 *$ & 1.000 & & & & & & \\
\hline roa & $-0.136^{*}$ & $0.085^{*}$ & 1.000 & & & & & \\
\hline returngrow & -0.023 & -0.013 & $0.163^{*}$ & 1.000 & & & & \\
\hline lev & 0.037 & $0.202 *$ & -0.043 & $-0.055^{*}$ & 1.000 & & & \\
\hline salegrow & 0.029 & -0.040 & $0.089^{*}$ & $0.227 *$ & $-0.102^{*}$ & 1.000 & & \\
\hline$m t b$ & $-0.059^{*}$ & 0.016 & $0.462 *$ & $0.074 *$ & 0.000 & $0.060 *$ & 1.000 & \\
\hline
\end{tabular}

All variables are defined in Table $1 .{ }^{*} p<0.1$ 
Table 4: Regression analysis of female directors and female and male financial experts on audit committees (Audit fees)

\begin{tabular}{|c|c|c|}
\hline & Female directorship & $\begin{array}{l}\text { Female and male } \\
\text { financial experts }\end{array}$ \\
\hline acfem & $\begin{array}{c}0.489 * * \\
(2.613)\end{array}$ & \\
\hline femacc & & $\begin{array}{l}0.582^{*} \\
(1.725)\end{array}$ \\
\hline femfinance & & $\begin{array}{c}0.080 \\
(0.280)\end{array}$ \\
\hline femsuper & & $\begin{array}{c}0.470 \\
(1.045)\end{array}$ \\
\hline mlacc & & $\begin{array}{c}-0.284 \\
(-1.291)\end{array}$ \\
\hline mlfinance & & $\begin{array}{c}-0.190 \\
(-0.678)\end{array}$ \\
\hline mlsuper & & $\begin{array}{c}-0.023 \\
(-0.094)\end{array}$ \\
\hline acind & $\begin{array}{c}0.013 \\
(0.027)\end{array}$ & $\begin{array}{c}0.077 \\
(0.173)\end{array}$ \\
\hline acsize & $\begin{array}{c}-0.022 \\
(-0.653)\end{array}$ & $\begin{array}{c}-0.016 \\
(-0.463)\end{array}$ \\
\hline acmeet & $\begin{array}{c}-0.014 \\
(-0.368)\end{array}$ & $\begin{array}{c}-0.009 \\
(-0.248)\end{array}$ \\
\hline boardind & $\begin{array}{c}1.186 * * * \\
(2.944)\end{array}$ & $\begin{array}{c}1.106 * * * \\
(2.678)\end{array}$ \\
\hline nonauditfee & $\begin{array}{c}0.288 * * * \\
(4.666)\end{array}$ & $\begin{array}{c}0.296 * * * \\
(4.662)\end{array}$ \\
\hline size & $\begin{array}{c}0.491 * * * \\
(11.670)\end{array}$ & $\begin{array}{c}0.495 * * * \\
(10.940)\end{array}$ \\
\hline stock & $\begin{array}{l}-0.448 \\
(-1.457)\end{array}$ & $\begin{array}{l}-0.418 \\
(-1.349)\end{array}$ \\
\hline$d e b t$ & $\begin{array}{c}2.939 * * * \\
(3.822)\end{array}$ & $\begin{array}{c}2.849 * * * \\
(3.751)\end{array}$ \\
\hline london & $\begin{array}{c}0.224 * * \\
(2.242)\end{array}$ & $\begin{array}{l}0.194^{*} \\
(1.832)\end{array}$ \\
\hline subsidiary & $\begin{array}{c}0.216 * * * \\
(5.177)\end{array}$ & $\begin{array}{c}0.211 * * * \\
(4.898)\end{array}$ \\
\hline roa & $\begin{array}{l}-0.607^{*} \\
(-1.950)\end{array}$ & $\begin{array}{l}-0.567^{*} \\
(-1.949)\end{array}$ \\
\hline Constant & $\begin{array}{c}-3.785^{* * *} * \\
(-5.570)\end{array}$ & $\begin{array}{c}-3.756^{* * *} \\
(-5.540)\end{array}$ \\
\hline Observations & 770 & 761 \\
\hline Adjusted $\mathrm{R}^{2}$ & 0.821 & 0.820 \\
\hline Year effects & YES & YES \\
\hline Industry effects & YES & YES \\
\hline F Test & $82.73 * * *$ & $78.31 * * *$ \\
\hline
\end{tabular}

Column 1 reports the results on the link between female directors on audit committees and audit fees. Column 2 
presents the results for the relation between the types of female and male financial experts on audit committees and audit fees. All standard errors are clustered at the firm level. Reported results include $t$-statistics in parentheses along with coefficients. All variables are defined in Table 1. *** $p<0.01, * * p<0.05$, * $p<0.1$

Table 5: Probit regression (Meeting or beating the zero earnings benchmark)

\begin{tabular}{|c|c|c|}
\hline & Female directorship & $\begin{array}{l}\text { Female and male } \\
\text { financial experts }\end{array}$ \\
\hline acfem & $\begin{array}{c}-1.014 * * * \\
(-2.888)\end{array}$ & \\
\hline femacc & & $\begin{array}{l}-1.327 * \\
(-1.706)\end{array}$ \\
\hline femfinance & & $\begin{array}{l}-0.181 \\
(-0.312)\end{array}$ \\
\hline femsuper & & $\begin{array}{c}-0.595 \\
(-0.710)\end{array}$ \\
\hline mlacc & & $\begin{array}{c}0.426 \\
(0.909)\end{array}$ \\
\hline mlfinance & & $\begin{array}{c}0.544 \\
(1.209)\end{array}$ \\
\hline mlsuper & & $\begin{array}{c}0.118 \\
(0.300)\end{array}$ \\
\hline acind & $\begin{array}{c}-3.043 * * * \\
(-2.748)\end{array}$ & $\begin{array}{c}-2.117 * * * \\
(-2.677)\end{array}$ \\
\hline acsize & $\begin{array}{l}-0.087 \\
(-1.450)\end{array}$ & $\begin{array}{l}-0.205 * * \\
(-2.452)\end{array}$ \\
\hline acmeet & $\begin{array}{l}-0.096 * * \\
(-2.351)\end{array}$ & $\begin{array}{c}-0.0879 * * \\
(-2.170)\end{array}$ \\
\hline boardind & $\begin{array}{c}-0.128 \\
(-0.192)\end{array}$ & $\begin{array}{c}0.642 \\
(0.693)\end{array}$ \\
\hline size & $\begin{array}{c}0.205 * * * \\
(3.849)\end{array}$ & $\begin{array}{l}0.108^{*} \\
(1.654)\end{array}$ \\
\hline returngrow & $\begin{array}{l}-0.268^{*} \\
(-1.791)\end{array}$ & $\begin{array}{c}-0.417 \\
(-1.633)\end{array}$ \\
\hline lev & $\begin{array}{c}0.655 * * \\
(2.065)\end{array}$ & $\begin{array}{c}0.435 \\
(1.175)\end{array}$ \\
\hline salegrow & $\begin{array}{c}0.038 \\
(0.152)\end{array}$ & $\begin{array}{c}-0.322 \\
(-0.781)\end{array}$ \\
\hline$m t b$ & $\begin{array}{c}-0.002 \\
(-1.080)\end{array}$ & $\begin{array}{c}-0.001 \\
(-1.038)\end{array}$ \\
\hline Constant & $\begin{array}{c}0.032 \\
(0.025)\end{array}$ & $\begin{array}{c}-0.259 \\
(-0.196)\end{array}$ \\
\hline Observations & 1,130 & 1,119 \\
\hline Pseudo $\mathrm{R}^{2}$ & 0.136 & 0.141 \\
\hline Year effects & YES & YES \\
\hline Industry effects & YES & YES \\
\hline Wald test & $101.57 * * *$ & $139.59 * * *$ \\
\hline
\end{tabular}

Column 1 reports the results for the association between female directors on audit committees and the propensity to meet or beat the zero earnings benchmark. Column 2 presents the results for the relation between the types of 
female and male financial experts on the audit committee and meeting or beating the zero earnings benchmark. Standard errors are clustered at the firm level. Reported results include $z$-statistics in parentheses along with coefficients. All variables are defined in Table 1. $* * * p<0.01, * * p<0.05, * p<0.1$

Table 6: Additional tests (Audit fees)

\begin{tabular}{|c|c|c|}
\hline & $\begin{array}{c}\text { Dummy (Female } \\
\text { accounting experts) }\end{array}$ & Matched sample \\
\hline dumfemacc & $\begin{array}{c}0.169 * * \\
(2.126)\end{array}$ & \\
\hline femacc & & $\begin{array}{c}0.599 * \\
(1.779)\end{array}$ \\
\hline acind & $\begin{array}{c}0.165 \\
(0.373)\end{array}$ & $\begin{array}{c}-0.079 \\
(-0.131)\end{array}$ \\
\hline acsize & $\begin{array}{c}-0.008 \\
(-0.210)\end{array}$ & $\begin{array}{c}-0.006 \\
(-0.132)\end{array}$ \\
\hline acmeet & $\begin{array}{c}-0.014 \\
(-0.376)\end{array}$ & $\begin{array}{c}0.022 \\
(0.621)\end{array}$ \\
\hline boardind & $\begin{array}{l}1.137 * * * \\
(2.842)\end{array}$ & $\begin{array}{c}1.028 \\
(1.567)\end{array}$ \\
\hline nonauditfee & $\begin{array}{c}0.282 * * * \\
(4.628)\end{array}$ & $\begin{array}{c}0.414 * * * \\
(2.842)\end{array}$ \\
\hline size & $\begin{array}{c}0.502 * * * \\
(11.670)\end{array}$ & $\begin{array}{c}0.407 * * * \\
(3.637)\end{array}$ \\
\hline stock & $\begin{array}{c}-0.436 \\
(-1.431)\end{array}$ & $\begin{array}{c}-0.465 \\
(-1.022)\end{array}$ \\
\hline$d e b t$ & $\begin{array}{c}2.880 * * * \\
(3.957)\end{array}$ & $\begin{array}{c}3.435 * * * \\
(4.074)\end{array}$ \\
\hline london & $\begin{array}{l}0.188^{*} \\
(1.846)\end{array}$ & $\begin{array}{c}-0.095 \\
(-0.634)\end{array}$ \\
\hline subsidiary & $\begin{array}{c}0.211 * * * \\
(5.032)\end{array}$ & $\begin{array}{c}0.178 * * * \\
(3.129)\end{array}$ \\
\hline roa & $\begin{array}{l}-0.582 * \\
(-1.776)\end{array}$ & $\begin{array}{c}-0.353 \\
(-0.401)\end{array}$ \\
\hline Constant & $\begin{array}{c}-4.008 * * * \\
(-5.789)\end{array}$ & $\begin{array}{c}-3.051 * * \\
(-2.442)\end{array}$ \\
\hline Observations & 770 & 200 \\
\hline Adjusted $\mathrm{R}^{2}$ & 0.820 & 0.839 \\
\hline Year effects & YES & YES \\
\hline Industry effects & YES & YES \\
\hline F Test & $83.23 * * *$ & $93.63 * * *$ \\
\hline
\end{tabular}

This table presents the results after performing additional tests on the association between female accounting experts on audit committees and audit fees. Column 1 utilises a dummy variable method to ascertain female accounting experts. Column 2 reports the results based on the propensity score matched sample. All standard errors are clustered at the firm level. Reported results include $t$-statistics in parentheses along with coefficients. All variables are defined in Table $1 . * * * p<0.01, * * p<0.05, * p<0.1$ 
Table 7: Additional tests (Meeting or beating the zero earnings benchmark)

\begin{tabular}{|c|c|c|c|}
\hline & Dummy & $\begin{array}{l}\text { Alternative cut- } \\
\text { off value }\end{array}$ & Matched sample \\
\hline dumfemacc & $\begin{array}{l}-0.367^{*} \\
(-1.801)\end{array}$ & & \\
\hline femacc & & $\begin{array}{l}-1.593^{*} \\
(-1.686)\end{array}$ & $\begin{array}{c}-1.753 * * \\
(-2.126)\end{array}$ \\
\hline acind & $\begin{array}{c}-2.181 * * * \\
(-2.968)\end{array}$ & & $\begin{array}{c}-2.099 \\
(-1.184)\end{array}$ \\
\hline acsize & $\begin{array}{c}-0.189 * * \\
(-2.361)\end{array}$ & $\begin{array}{c}-0.211 * * \\
(-2.356)\end{array}$ & $\begin{array}{c}-0.205 \\
(-1.578)\end{array}$ \\
\hline acmeet & $\begin{array}{c}-0.083 * * \\
(-2.089)\end{array}$ & $\begin{array}{l}-0.101^{*} \\
(-1.815)\end{array}$ & $\begin{array}{l}-0.151^{*} \\
(-1.764)\end{array}$ \\
\hline boardind & $\begin{array}{c}0.583 \\
(0.663)\end{array}$ & $\begin{array}{l}1.192 \\
(1.037)\end{array}$ & $\begin{array}{c}0.074 \\
(0.053)\end{array}$ \\
\hline size & $\begin{array}{l}0.105^{*} \\
(1.668)\end{array}$ & $\begin{array}{c}0.059 \\
(0.754)\end{array}$ & $\begin{array}{c}0.240 * * \\
(2.162)\end{array}$ \\
\hline returngrow & $\begin{array}{l}-0.285 \\
(-1.151)\end{array}$ & $\begin{array}{c}0.120 \\
(0.556)\end{array}$ & $\begin{array}{c}-0.166 \\
(-0.429)\end{array}$ \\
\hline lev & $\begin{array}{c}0.368 \\
(1.015)\end{array}$ & $\begin{array}{c}0.644 \\
(1.526)\end{array}$ & $\begin{array}{c}0.278 \\
(0.401)\end{array}$ \\
\hline salegrow & $\begin{array}{c}-0.328 \\
(-0.822)\end{array}$ & $\begin{array}{c}-0.219 \\
(-0.400)\end{array}$ & $\begin{array}{c}-0.369 \\
(-0.665)\end{array}$ \\
\hline$m t b$ & $\begin{array}{c}-0.001 \\
(-0.868)\end{array}$ & $\begin{array}{c}0.000 \\
(0.087)\end{array}$ & $\begin{array}{c}-0.001 \\
(-0.372)\end{array}$ \\
\hline Constant & $\begin{array}{c}0.329 \\
(0.262)\end{array}$ & $\begin{array}{c}-1.712 \\
(-1.378)\end{array}$ & $\begin{array}{c}-1.032 \\
(-0.452)\end{array}$ \\
\hline Observations & 1,130 & 1,038 & 249 \\
\hline Pseudo $\mathrm{R}^{2}$ & 0.129 & 0.121 & 0.166 \\
\hline Year effects & YES & YES & YES \\
\hline Industry effects & YES & YES & YES \\
\hline Wald test & $111.68 * * *$ & $189.61 * * *$ & $47.51 * * *$ \\
\hline
\end{tabular}

This table presents the results after performing additional tests on the association between female accounting experts on audit committees and the propensity to meet or beat the zero earnings benchmark. Column 1 adopts a dummy variable method to ascertain female accounting experts. Column 2 determines meeting or beating the zero earnings benchmark by utilising an alternative cut-off value of 0-0.01. Further, in Column 2, audit committee independence is dropped because applying a lower cut-off value resulted in all firm-year observations with a fully independent audit committee. Column 3 reports the results based on the propensity score matched sample. Standard errors are clustered at the firm level. Reported results include $z$-statistics in parentheses along with coefficients. All variables are defined in Table 1. *** $p<0.01, * * p<0.05, * p<0.1$ 
Table 8: Additional test incorporating possible omitted variables [including going concern opinion and financial reporting quality (discretionary accruals)] and tokenism

\begin{tabular}{|c|c|c|c|c|c|c|c|c|}
\hline & audfee & meetbeat & audfees & meetbeat & audfee & meetbeat & audfee & meetbeat \\
\hline & \multicolumn{4}{|c|}{$\begin{array}{l}\text { Test for checking the effect of omitted } \\
\text { variables }\end{array}$} & \multicolumn{4}{|c|}{$\begin{array}{l}\text { Test for checking the effect of tokenism } \\
\text { [when the presence of female director is } \\
\text { two or above] }\end{array}$} \\
\hline acfem & $\begin{array}{l}0.520 * * * \\
(2.661)\end{array}$ & $\begin{array}{c}-0.101 * * * \\
(-2.793)\end{array}$ & & & $\begin{array}{l}0.661^{*} \\
(1.835)\end{array}$ & $\begin{array}{l}-0.124^{*} \\
(-1.793)\end{array}$ & & \\
\hline femacc & & & $\begin{array}{c}0.343 * * * \\
(2.990)\end{array}$ & $\begin{array}{c}-0.053 \\
(-1.612)\end{array}$ & & & $\begin{array}{l}0.395^{*} \\
(1.713)\end{array}$ & $\begin{array}{c}0.042 \\
(1.011)\end{array}$ \\
\hline femfinance & & & $\begin{array}{c}0.371 * * * \\
(4.312)\end{array}$ & $\begin{array}{c}0.022 \\
(0.243)\end{array}$ & & & $\begin{array}{c}0.322 \\
(0.583)\end{array}$ & $\begin{array}{c}0.032 \\
(0.862)\end{array}$ \\
\hline femsuper & & & $\begin{array}{c}0.039 \\
(1.184)\end{array}$ & $\begin{array}{c}-0.072 \\
(-0.878)\end{array}$ & & & $\begin{array}{c}0.383 \\
(0.548)\end{array}$ & $\begin{array}{l}-0.211^{*} \\
(-1.732)\end{array}$ \\
\hline mlacc & & & $\begin{array}{c}0.257 \\
(0.989)\end{array}$ & $\begin{array}{c}0.089 \\
(1.295)\end{array}$ & & & $\begin{array}{c}0.394 \\
(0.592)\end{array}$ & $\begin{array}{c}0.112 \\
(0.928)\end{array}$ \\
\hline mlfinance & & & $\begin{array}{c}0.532 * * \\
(2.031)\end{array}$ & $\begin{array}{c}0.055 \\
(0.492)\end{array}$ & & & $\begin{array}{c}0.600 \\
(1.080)\end{array}$ & $\begin{array}{c}-0.057 \\
(-1.066)\end{array}$ \\
\hline mlsuper & & & $\begin{array}{c}0.823 * * * \\
(2.918)\end{array}$ & $\begin{array}{c}0.023 \\
(1.111)\end{array}$ & & & $\begin{array}{c}0.302 \\
(0.991)\end{array}$ & $\begin{array}{c}-0.044 \\
(-0.418)\end{array}$ \\
\hline $\begin{array}{l}\text { Control } \\
\text { variables }\end{array}$ & YES & YES & YES & YES & YES & YES & YES & YES \\
\hline $\begin{array}{l}\text { Industry } \\
\text { effects }\end{array}$ & YES & YES & YES & YES & YES & YES & YES & YES \\
\hline Year effects & YES & YES & YES & YES & YES & YES & YES & YES \\
\hline Observation & 753 & 739 & 753 & 739 & 249 & 249 & 249 & 249 \\
\hline F-statistic & $82.512 * * *$ & - & $79.154 * * *$ & - & $77.589 * * *$ & - & $76.060 * * *$ & - \\
\hline Wald Test & - & $122.214 * * *$ & - & $124.491 * * *$ & - & $118.121^{* * *}$ & - & $119.214^{* * *}$ \\
\hline $\begin{array}{l}\text { Adjusted } R^{2} \\
\text { Pseudo- } R^{2}\end{array}$ & $\begin{array}{c}0.845 \\
-\end{array}$ & $\begin{array}{c}- \\
0.054\end{array}$ & $\begin{array}{c}0.854 \\
-\end{array}$ & $\begin{array}{c}- \\
0.115\end{array}$ & $\begin{array}{c}0.265 \\
-\end{array}$ & $\begin{array}{c}- \\
0.171\end{array}$ & $\begin{array}{c}0.268 \\
-\end{array}$ & $\begin{array}{c}- \\
0.195\end{array}$ \\
\hline
\end{tabular}

All standard errors are clustered at the firm level. Reported results include $t$-statistics (Column 1, 3, 5 and 7) and $z$-statistics (Column 2, 4, 6 and 8) in parentheses along with coefficients. All variables are defined in Table 1. *** $p<0.01, * * p<0.05, * p<0.1$ 
Appendix

Table A.1: Mean difference (Audit fees)

\begin{tabular}{lrrr}
\hline & Treated & Control & $p$-value \\
\hline acind & 0.992 & 0.977 & 0.260 \\
acsize & 4.350 & 4.470 & 0.494 \\
acmeet & 4.770 & 4.530 & 0.314 \\
boardind & 0.606 & 0.587 & 0.251 \\
nonauditfee & 6.481 & 6.317 & 0.440 \\
size & 15.475 & 15.297 & 0.419 \\
stock & 0.136 & 0.164 & 0.319 \\
debt & 0.105 & 0.119 & 0.250 \\
london & 0.860 & 0.850 & 0.842 \\
subsidiary & 3.013 & 2.862 & 0.290 \\
roa & 0.091 & 0.079 & 0.151 \\
\hline Co
\end{tabular}

Column 1 and 2 in this table shows the mean values of observable firm characteristics for treated (presence of a female accounting expert on the audit committee) and control (absence of a female accounting expert on the audit committee) firms after nearest neighbour matching. Column 3 reports the $p$-values for the mean differences. All variables are defined in Table 1. 
Table A.2: Mean difference (Meeting or beating the zero earnings benchmark)

\begin{tabular}{lrrr}
\hline & Treated & Control & $p$-value \\
\hline acind & 0.995 & 0.992 & 0.588 \\
acsize & 4.107 & 4.095 & 0.914 \\
acmeet & 4.681 & 4.663 & 0.917 \\
boardind & 0.595 & 0.606 & 0.349 \\
size & 15.094 & 15.111 & 0.921 \\
returngr & 0.144 & 0.093 & 0.250 \\
lev & 0.647 & 0.643 & 0.857 \\
salegr & 0.069 & 0.041 & 0.213 \\
mtb & 4.866 & 6.129 & 0.823 \\
\hline
\end{tabular}

Column 1 and 2 in this table shows the mean values of observable firm characteristics for treated (presence of a female accounting expert on the audit committee) and control (absence of a female accounting expert on the audit committee) firms after nearest neighbour matching. Column 3 reports the $p$-values for the mean differences. All variables are defined in Table 1. 